\title{
PRIVATE FOUNDATION IN THE POLISH LEGAL SYSTEM AS A SPECIFIC INSTITUTION OF THE CIVIL SOCIETY
}

\author{
dr Joanna PODGÓRSKA-RYKAKA \\ dr Marcin KĘPA
}

\begin{abstract}
The paper is an attempt to analyze the selected features and legal regulations related to foundation's institutions, as defined in Polish law, as the specific institution of the civil society. As Authors, we are trying to follow the path of one of the most important problems regarding the theory on the civil society, taking the form of the question about locating the civil society somewhere between the public and private spheres. These issues can be especially clearly illustrated with an example or foundation's institutions, as listing socially or economically useful goals by the lawmakers determine some scope of essential problems seen (not listed here) that could be expressed in the form of the two questions. Firstly, can a foundation be considered a social organization at all? Secondly, can a foundation perform only business activities, as the lawmakers used the conjunction typical for the nonexclusive disjunction? We think there is no simple answer for questions formed in such a way. The considerations included in this paper are included in the scope of social sciences, with particular attention paid to legal sciences and political and administrative science. This text should be qualified as interdisciplinary, though also oriented mostly to analyze legal, economic and social conditions of the essence of a foundation, as the specific formula within which tasks typical for civil society organizations can be executed.
\end{abstract}

\section{Keywords}

foundation, civil society, foundation as estate

\section{Introduction}

According to Edward Shils, "citizenship is acceptance of one's obligation to act (at least to some extent) for the common good, when making decisions related to conflicting interests or ideas, ordering to consider consequences of certain actions performed for common good or society as a whole. Popularization of this civic attitude allows to maintain equilibrium among various competing and conflicting elements of society. Keeping this equilibrium allows society to operate as a coherent unity and not as, for example, a specific 
by-product of competition and conflicts among society's groups. A society within which impact of this active civic element is relatively significant, can be considered a civil society. ${ }^{\prime 1}$ When focusing on specific legal and organizational forms, i.e. official institutions, it is assumed that a civil society is "entirety of non-state civil institutions, organizations and associations acting in the public sphere. These structures are relatively independent from state, emerging as grassroots movements and generally characterized by voluntary membership." ${ }^{2}$ Within the Polish foundation-related law we can distinguish the three following types of foundations: private legal foundations, public legal foundations and religious foundations. This paper focuses only on the first type of foundations, i.e. private legal entities, as in Poland they are much more frequent than the two other categories. The foundations and the associations being subject of this paper has been directly qualified by the Polish lawmakers to this type of organizations, that results from the art. 3 sect. 2 clause 2 of the Act of April 24, 2003 on Work for Public Benefit and Voluntary Service.

Even when legally classified as "typical", non-governmental organizations are entities that should be dealt with in the very broad context. These institutions are impossible to be analyzed without consideration of the interdisciplinary perspective. However, as this is a law-related paper, the analysis conducted herein is going to have the definitely legal character. The origins of what we are nowadays calling a foundation are derived from ancient Rome. These institutions, sensu largo, defined as specifically oriented permanent activities of a founder, had their previous, though insufficiently determined types. Primary forms of foundations did not definitely match the legal structure developed by means of positive law in the 19th century in Western Europe, by which we mean the currently immanent features typical for foundations, namely legal personality, considering them as company legal entities, having a goal, assets and respective organizational structure enabling performance of founder's will and executing only goals that are useful socially or economically. ${ }^{3}$

Hubert Izdebski ${ }^{4}$ underlines the non-corporate character of a foundation, putting it in contrary to the legal structure of association (association of persons). He also indicates some formal and legal, as well as substantive-law-related similarities, including acting on the basis of a statute, entry to a respective register and legal personality. Indeed, corporate personhood entities, such as cooperatives or associations, are oriented to persons, while foundations, to the contrary, to property. As a consequence of such a legal structure, foundations have their beneficiaries, not members. As a result, one cannot be granted membership in a foundation, but can become its member. On the other hand, a foundation, as being oriented to execution of its goal in the social and economic context and not oriented to persons, is also not a typical "fund". ${ }^{5}$

The indicated features of a foundation emphasize its essence and related evident distinctiveness from other institutions of the civil society in Poland. While dealing with

1 SHILS, Edward: Co to jest społeczeństwo obywatelskie, [in:] K. Michalski (eds.), Europa i społeczeństwo obywatelskie. Rozmowy w Castel Gandolfo, Wydawnictwo Znak, Kraków 1994, 11-12.

2 WNUK-LIPIŃSKI, Edmund: Socjologia życia publicznego, Warszawa 2005, 119.

$3 \mathrm{ClOCH}$, Henryk: Prawo fundacyjne, Kraków 2007, 27-28.

4 IZDEBSKI, Hubert: Fundacje i stowarzyszenia. Komentarz, Krasnobród 2004, 20.

5 Funds are separate bank accounts without legal personality, being at disposal of a given minister. 
these issues, we discuss the most important aspects related to the essence of a foundation, in particular its assets and certain aspects of foundation's admissibility to conduct business activity, as a foundation is nothing more than personified property and a method of its use is to be determined by a founder in a statute. ${ }^{6}$ Execution of foundation's goal is funded either from assets (primary assets, primary accumulation) or incomes they produce. ${ }^{7}$ When focusing on such defined issues, this paper is an attempt to analyze the selected features and legal regulations related to foundation's institutions, as defined in Polish law, as the specific institution of the civil society. ${ }^{8}$ As Authors, we are trying to follow the path of one of the most important problems regarding the theory on the civil society, taking the form of the question about locating the civil society somewhere between the public and private spheres. These issues can be especially clearly illustrated with an example or foundation's institutions, as listing socially or economically useful goals by the lawmakers determine some scope of essential problems seen (not listed here) that could be expressed in the form of the two questions. Firstly, can a foundation be considered a social organization at all? Referring to a foundation by calling it a social organization is a bit problematic, because in Poland there is no well-established jurisprudence regarding this matter and there are discrepancies between theses included in judicial verdicts and scientific papers. Secondly, can a foundation perform only business activities, as the lawmakers used the conjunction typical for the non-exclusive disjunction? Business activities of a foundation need to be secondary (auxiliary) to the main social goal. We think there is no simple answer for questions formed in such a way. The considerations included in this paper are included in the scope of social sciences, with particular attention paid to legal sciences and political and administrative science. The problems included in this paper should be classified as interdisciplinary and mostly focusing on research on legal, economic and social determinants of the essence of a foundation as a specific form within which goals typical for civil society organizations can be achieved. However, the authors of this paper focused mostly on extension of the legal thread, while the other ones will be investigated in further research on foundations.

\footnotetext{
6 WRZEŚNIEWSKI, Paweł: Ustawa o fundacjach. Komentarz praktyczny, Warszawa 2011, 11.

7 WOLTER, Aleksander: Prawo cywilne, Warszawa 1996, 24.

8 The paper builds on previous research conducted by the Authors, whose results were published in the following monograph KĘPA, Marcin, PODGÓRSKA-RYKAŁA, Joanna: Prawo o fundacjach. Komentarz do ustawy o fundacjach. Działalność fundacji w praktyce. Wzory dokumentów, C.H. Beck, Warszawa 2020.
} 


\section{Civil society}

Civil society is a term that cannot be clearly or finally defined. Its definition is a result of plentiful of approaches related to multidimensionality of this phenomenon and resulting in unabated interest in the term of civil society among various researchers. They represent not only the broadly defined social sciences and humanities, ${ }^{9}$ resulting in abundant and multi-faceted literature, ${ }^{10}$ that is obvious, because civil society is the sophisticated conglomerate of various philosophical, sociological, historical, anthropological, legal, cultural, esthetical and political-science-related ideas. On the other hand, civil society is the set of specific and dynamic forms of social self-organization, that still go unnoticed by various researchers. ${ }^{11}$

Considering the above, the first step that should be taken in order to define this phenomenon is performance of simplification and identification of civil society, in context of this paper, with formal or informal groups or organizations that express diversified social interests, acting independently from state structures, ${ }^{12}$ by achieving social goals and performing public tasks. It is worth noting that the role and importance of such defined civil society organizations in modern societies are shaped by the fact of being located between power and society and is expressed via the intermediary function. ${ }^{13}$ Apart from articulation of needs, organizations also take responsibility for execution of tasks from various areas of social life. It seems that the intermediary function between society and market (economy) on the one side and state on the other, regarding provision of social services and achievement of other

9 See, e.g.: ALMOND, Gabriel and VERBA, Sidney: Kultura polityczna, [in:] J. Szczupaczyński (eds.), Władza i społeczeństwo. Antologia tekstów z zakresu socjologii polityki, Scholar, Warszawa 1995; BAUMEISTER, Roy F. and BRATSLAVSKY, Ellen and FINKENAUER, Catrin and VOHS, Kathleen D.: Bad is stronger than good, "Review of General Psychology", 2001, no. 5; BURT, Ronald Stuart: Structural Holes. The Social Structure and Competition, Harvard University Press, Cambridge 1992; KOTARBIŃSKI, Tadeusz: Witkiewicz: Pojęcia i twierdzenia implikowane przez pojęcie istnienia, "Przegląd Filozoficzny", 1936, no. 2; LAPORTA, Rafael and LOPEZ-DE-SILANES, Florencio and SHLEIFER, Andrei and VISHNY, Robert W.: Trust in large organizations, "American Economic Review", 1997, no. 57; LIN, Nan: Social Capital. A Theory of Social Structure and Action, Cambridge University Press, New York 2001; SIDANIUS, Jim and PRATTO, Felicia: Social dominance: An intergroup theory of social hierarchy and oppression, Cambridge University Press, New York 1999; SOIN, Maciej: Filozofia Stanisława Ignacego Witkiewicza, Ossolineum, Wrocław 2002.

10 Cf., i.a.: OGRODZIŃSKI, Paweł: Pięć tekstów o społeczeństwie obywatelskim, Instytut Studiów Politycznych Polskiej Akademii Nauk, Warszawa 1991; HALL, Judith A.: Civil Society. Theory, History, Comparison, Polity Press, Cambridge 1995; WITKOWSKA, Marta and WIERZBICKI, Andrzej (eds.), Społeczeństwo obywatelskie, Oficyna Wydawnicza ASPRA-JR, Warszawa 2005; SZACKI, Jerzy: Ani książę, ani kupiec - obywatel: idea społeczeństwa obywatelskiego w myśli współczesnej, Znak, Kraków 1997; MICHALSKI, Krzysztof (ed.), Europa i społeczeństwo obywatelskie. Rozmowy w Castel Gandolfo, Wydawnictwo Znak, Kraków 1994; FERGUSON, Adam: An Essay on the History of Civil Society, Edinburgh Univeristy Press, Edinburgh 1966; PIETRZYK-REEVES, Dorota: Idea społeczeństwa obywatelskiego. Współczesna debata i jej źródła, FNP, Wrocław 2004; COHEN, Jean and ARATO, Andrew: Civil Society and Political Theory, MIT Press, Cambridge Mass. 1994; GÓRSKI, Eugeniusz: Rozważania o społeczeństwie obywatelskim i inne studia z historii idei, IFiS PAN, Warszawa 2003; KAVIRAJ, Sudipta and KHILNANI, Sunil: Civil Socjety: History and Possibilities, Cambridge 2001.

11 Cf.: PODGÓRSKA-RYKAŁA, Joanna and KĘPA, Marcin: Współpraca międzysektorowa jednostek samorządu terytorialnego z organizacjami pozarządowymi, Wydawnictwo Libron, Kraków 2020.

12 Społeczeństwo obywatelskie, WITKOWSKA, Marta and WIERZBICKI Andrzej (eds.), Oficyna Wydawnicza ASPRA-JR, Warszawa 2005, 9.

13 OFFE, Claus: Nowe ruchy społeczne. Przekraczanie granic polityki instytucjonalnej, [in:] J. Szczupaczyński (eds.), Władza i społeczeństwo, Wydawnictwo Naukowe „Scholar”, Warszawa 1995. 
goals, constitutes "the source of intense development of the third sector and increase of forms of its institutions and goal achievement methods." 14

The primary legal act regarding the area of civil society in Poland is the Constitution of the Republic of Poland of April 2, 1997. ${ }^{15}$ This basic law refers to civil society organizations in its art. 12 by stating that the Republic of Poland shall ensure freedom for the creation and functioning of trade unions, socio-occupational organizations of farmers, societies, citizens' movements and other voluntary associations and foundations. The art. 13 of the said document states that political parties and organizations whose programmes are based upon totalitarian methods and the modes of activity of Nazism, fascism and communism, as well as those whose programmes or activities sanction racial or national hatred, the application of violence for the purpose of obtaining power or to influence the State policy, or provide for the secrecy of their own structure of membership, shall be prohibited. In turn, the art. 58 sect. 1 of the Constitution shall guarantee to everyone the freedom of association. These regulations form the primary guarantee of freedom of civil society in a democratic state. ${ }^{16}$ Social organizations are one of components of the civil society, however they have not been legally defined in Polish law, thus this definition is being shaped in judicial verdicts. By expounding the art. 12 of the Constitution of the Republic of Poland, the Supreme Administrative Court indicated five common features of social organizations, namely:

(1) organizations consisting of a certain group of people, based on voluntary membership,

(2) organizations referenced by specific sets of regulations determining their structure, scope of rights and obligations defining their organizational distinctiveness and independence,

(3) scope of activity and goals of organizations are primarily defined in statues and must be compliant with state goals, (4) members of bodies in these organizations are elected by those who belong to them and (5) organizations are controlled or supervised by public state authorities. ${ }^{17}$

On the other hand, Polish law defines the term of a non-governmental organization. According to the Act of April 24, 2003 on Work for Public Benefit and Voluntary Service, ${ }^{18}$ non-governmental organizations in Poland are legal persons or organizational units, including foundations and associations, without legal personality that is granted to them on the basis of the separate act, with the reservation they must not: (1) be units of the public finance sector or entrepreneurs, research institutions, banks and commercial law companies being state or local government legal entities or (2) act with purpose to gain profit. The art. 3 sect. of the said act also indicates the so called other entities that are not included in the definition of a non-governmental organizations, but still conduct work for public benefit. These are: church and religious organizations, associations of local government entities, social cooperatives and sports clubs. In general, Polish law defines three forms of creating and functioning of non-governmental organizations, namely: associations, foundations and organizations acting on the basis of separate acts.

14 GROTKOWSKI, Michał: Trzeci sektor w Polsce - rola i zagrożenia płynące z wypełniania funkcji i zadań administracji publicznej, "Forum Studiów i Analiz Politycznych", 2011, 2.

15 The Constitution of the Republic of Poland of April 2, 1997, Journal of Laws of 1997, 78, 483.

16 Cf.: PODGÓRSKA-RYKAŁA, Joanna and KĘPA, Marcin: Współpraca międzysektorowa jednostek samorządu terytorialnego z organizacjami pozarządowymi, Wydawnictwo Libron, Kraków 2020.

17 Resolution of the Polish Supreme Administrative Court of December 12, 2005, II OPS 4/05, Legalis.

18 Act of April 24, 2003 on Work for Public Benefits and Voluntary Service (Journal of Laws of 2018, 450). 


\section{Foundations as defined by the currently valid acts}

The legal act sufficiently defining the status of Polish foundations is the Act of April 6, 1984 on Foundations. ${ }^{19}$ According to its regulations, a foundation can be established for socially or economically useful goals, including health protection, development of economy and science, education and upbringing, culture and arts, care and social assistance, environmental protection and preservation of historical monuments, that will be compliant with the primary interests of the Republic of Poland. As a result of the essence of this organizational form, its initiator is a so called founder or founders who can be natural persons, regardless of citizenship and domicile, or legal persons with registered offices in Poland or abroad. Foundation's headquarters should be located in Poland, with reservation that if a foundation is to operate only in one voivodeship, it should be located therein. In order to establish a foundation a founder needs to present a declaration of will submitted in the form of a notarial act and clearly specifying foundation's goal and assets allocated for its achievement, excluding foundation established on the basis of a last will, when the notarial act form is not required. The lawmakers define assets as money, securities and movable and immovable property given to a foundation to take over. If a foundation is to perform business activity, value of its assets for this purpose must not be lower than 1,000 PLN.

Foundation operates on the basis of a status in which a founder (personally or via natural or legal persons they authorized) specifies its name, registered office and assets, goals, rules, forms and scope of operations, constitution and organization of a management board, method of its assignment and its obligations and rights, as well as its members. The said document can also define, though not obligatorily, issues related to conducting business activity that is permitted, but only within the scope compliant with achievement of foundation's goals. Additionally, a statute can define matters related to admissibility and conditions of possible merger with other foundation, change of goals or amendments in a statute and anticipate establishment of other foundation's bodies, apart from a management board. Only the latter one is the obligatory institution of a foundation and its duties consist in management of its operation and representation before third parties.

In order to operate correctly a foundation is subject to obligatory entry to the Polish National Court Register. A court investigates whether foundation's goal and statute are legal. Upon being entered to NCR a foundation is granted legal personality. Each statute amendment requires a new entry to NCR. Foundation submits an annual report on operations to a respective minister, in compliance with the template specified in an appropriate regulation, in order to check whether foundation's goals specified in its statute are properly executed. The said report is then made publicly accessible. If there are any doubts regarding correctness of foundation operations, certain institutions are authorized to take respective steps. Firstly, a respective minister or poviat starost is authorized to bring a motion before court to revoke a management board resolution being flagrantly inconsistent with foundation's goals or law, they can also file a motion before court to stop execution of a resolution until a verdict is issued. Additionally, the said institutions are entitled to determine a period for removal of defects in the form of a letter

19 Act of April 6, 1984 on Foundations, (Journal of Laws of 2018, 1491). 
of formal notice or demand to have foundation's management board be changed, if a management board acts in a way significantly violating the law or foundation's statute. If such an intervention is ineffective, the said institutions are authorized to file a motion before court to have a foundation management board suspended and to appoint compulsory administration. When the goal a foundation was established for is achieved or if its financial assets and property are run out, a foundation becomes subject to liquidation in a way specified in its statute. If a statute does not assume foundation liquidation, a respective minister or poviat starost submits a motion for liquidation before court. Assets of a liquidated foundation are to be disposed of as specified in a statute and if it does not contain respective provisions on this matter, a respective decision is made by court. As it can be concluded from the aforesaid provisions regarding foundations, the lawmakers specified such matters as foundation establishment, legal capacity, capacity to perform legal acts, foundation liquidation and foundation's financial status, while other matters are to be decided in a statute.

It is worth mentioning that the Act on Foundations specifies the legal framework of operations of foundations of private law in Poland in the area of legal and economic transactions. The said act does define operation of non-public foundations, i.e. civil law entities, however from inclusion therein the regulations regarding, for example, supervision over foundations by public institutions (respective minister or poviat starost) and defining this scope and making it related to judicial review (also administrative courts) it can be concluded that the Act on Foundations has a hybrid (mixed) structure with significant domination of civil law regulations over administrative law (public law) ones. The term of "this act" used by the lawmakers in the art. 4 of the Act on Foundations makes it clear that specific acts on foundation law will not be applied for private foundations, in particular acts and laws of a lower level, that determine functioning of public (public law) foundations. Even "respective application" was excluded, for example regarding the matters not regulated in the said act.

Matters not regulated by lawmakers are from time to time defined by statutes of given organizations. A statute is an internal legal act focusing on organizational operations that do not cause direct legal results for entities being in external legal relations with a foundation. However, foundation's status cannot be treated as an agreement, as in case of entities with corporate personhood. ${ }^{20} \mathrm{~A}$ statute is defined by a founder, possibly other natural or legal person they appointed, on the basis of a granted power of attorney, therefore they are not partners who are also founders of a legal person. As a result, a statute is not articles of incorporation and should be treated as a set of objective legal norms. ${ }^{21}$

\section{Foundation as estate}

There should be a reasonable equilibrium between foundation's goals and assets. A founder is obligated to secure a finance source with purpose to achieve goals of a foundation, if it is supposed to exist as actual legal existence. It should be noted that foundation is mostly assets and a company legal entity that, in contrary to associations, cannot

20 SUSKI, Paweł: Stowarzyszenia i fundacje, Warszawa 2018, 429.

21 NIEMIRKA, Bogusław: Statut fundacji, Warszawa 1995, 6. 
rely on work of its members. As a result, foundation actions are generally determined by assets secured (assigned, donated) by a founder. The lawmakers did not directly define foundation's initial assets, but they specifically listed some of their elements, namely money, securities and movable and immovable property. Although in judicial verdicts one can find the contradicting opinion on enumerated elements of foundation's assets in articles of incorporation, we find it wrong and unapprovable. ${ }^{22}$

Sufficiency of assets granted to a foundation in terms of achievement of its statutory goals are subject to assessment by registry courts. ${ }^{23}$ On the basis of an analysis of judicial verdicts in this field it can be concluded that an amount of initial capital, that is accepted by courts, is from 500 to 1,000 PLN (the upper threshold is clearly related to the situation of conducting business activity by a foundation, as if it is going to do so, the value of assets must not be lower than 1,000 PLN; in general, foundation's assets can by anything transferring or constituting value (e.g. payables on the account of a lease contract).

Although the lawmakers did not clearly explain that they meant only assets, when mentioning foundation's property, considering the specific legal structure of a foundation, it should be concluded they also meant liabilities, because the latter would have made functioning of a foundation and achievement of statute goals impossible. Listing of components of property are the obligatory element of articles of incorporation (apart from foundation's goals) and therefore it is necessary to mention them in a statute, too.

There are no obstacles for primary assets granted by a founder to be multiplied via efficient operations of foundation's management board, if only foundation's goal has not been achieved as a result of consumption of the primary assets, because it is worth noting that achievement of an assumed goal determines the fact of foundation's existence. If an assumed goal is achieved, a foundation is dissolved, despite the fact it can still possess even significant assets that will be disposed of specified in respective regulations, if the said case occurs. In order to avoid such a situation one can define only a general goal, ${ }^{24}$ because if a founder defines a detailed goal, for example in a last will, and it is, for instance, renovation of a cultural monument, a foundation becomes dissolved at the moment of achieving this goal in a way specified in its statute, as defined in the art. 15 of the Act on Foundations. A founder can decide on allocation of foundation's assets after its liquidation. The premise related to liquidation is applicable also in case of running out of foundation's financial assets and property.

If allocation offoundation's assets was specified in a statute afterfoundation's liquidation, they should be spent for purposes mentioned in the art. 1 of the Act on Foundations. The literal interpretation of the art. 5 sect. 4 in relation to the art. 1 of the Act of Foundations leads to the conclusion that, firstly, estate remaining after foundation's liquidation can be spent in particular for such purposes as health protection, development of economy and science, education and upbringing, culture and arts, care and social assistance, environmental protection and preservation of historical monuments, eventually other types of socially or economically useful goals, under the condition that these goals will be compliant with

22 Cf. the verdict of the Polish Supreme Administrative Court of October 13, 1999, IV SA 1349/97, Legalis.

23 Cf. the decision of the Polish Supreme Court of February 12, 2002, I CKN 1388/99, Legalis.

24 It is worth noting that establishment of a foundation "on behalf" is the wrong, though popularized, expression; this problem was already mentioned in the 1990s, cf. STECKI, Leopold: Fundacja. Część pierwsza, Toruń 1996, 145. 
the primary interests of the Republic of Poland. Secondly, they can be goals different from those realized by a foundation being liquidated and, thirdly, it is permitted to precisely identify an entity achieving goals specified in the art. 1 of the Act on Foundations, on behalf of which the assets of a foundation after its liquidation are supposed to be allocated (for example, other social economy entity).

\section{Conducting business activity by a foundation}

The decision to conduct business activity by a foundation is - apart from property-related issues - an equally critical element of a statute. Though it is not a sine qua non condition of a statutory act, information on the issue whether a foundation is going to be active in business transactions as an ideal foundation (executing solely a socially useful goal without an accompanying economically useful goal) is crucial, because reference to this matter in a statute during the registering procedure will, even if only rudimentarily, result in specific legal effects after a foundation is liquidated.

Foundations can perform activities in the industrial, trade and service sectors, at their own discretion. Conducting of business activity by foundations is correlated with their statutory goals and, in general, should lead to achievement of a primary (socially useful) goal. Even if the idea of conducting business activity by a foundation emerges later, for example as a result of amendment, transformation or supplementation of statutory goals (like subsidiary goals), a foundation can undertake business activity, if such a possibility was provided for in a statute.

Even failure to undertake business activity at the moment of establishment of a foundation does not constitute a permanent obstacle resulting in expiration of rights within this scope, but a decision on a ban to perform gainful activities is, indeed, such an obstacle. Undertaking business activity not specified in foundation's statute requires a previous amendment in a statute. In turn, an amendment in foundation's statute requires an update of an entry into the Polish National Court Register. According to judicial verdicts, it is prohibited to establish foundations of private law, whose exclusive sphere is to run a company ${ }^{25}$ and socially useful activities are a subsidiary goal. ${ }^{26}$ Therefore, in Poland we have the mixed model, i.e. the possibility to link the a foundation-related idea with gainful activities.

Foundations can conduct business activity within their own organizational structures (e.g. within unit's/plant's structure by defining its internal organization led by a director) or via other economic entities, for example trading companies. Considering the aforesaid criterion, we can distinguish the indirect and direct form of conducting business activity by foundations. The indirect form occurs, when a foundation defines within its organization a specific group of tangible and intangible assets for conducting business activity, while the direct form occurs, when a foundation decides to conduct business activity beyond its

25 As defined in Polish civil law, an entrepreneur is a natural person, legal person or organizational unit granted legal capacity by the respective act, conducting business activity in their own name (art. 431 of the Civil Code). The content of this provision was repeated in the unaltered form in the Entrepreneurs' Law (art. 4 sect. 1), extending the definition of entrepreneurs by partners of civil law partnerships within the scope of business activity performed by them (art. 4 sect. 2).

26 The verdict of the Polish Supreme Court of January 7, 1997, I CKN 16/96, Legalis. 
own organizational structure by, for example, establishing for this purpose a commercial law company or investing in a company already existing in such a way that type and extent of foundation's assets being involved make this entity a company dependent on this foundation.

It is worth noting that execution of a socially useful goal does not need to be related to undertaking and conducting business activity by a foundation. The logical and literal interpretation of the differentiation among socially and economically useful goals, specified in the art. 1 of the Act on Foundations, leads to the conclusion that an economically useful goal can be also a goal used for support of certain economic initiatives (for example certain economy sector or rather entities conducting business activity within this sector) without participation in an economic undertaking. Nevertheless, it became customary, in theory and practice, to link an economically useful goal with conducting of business activities by foundations. Business activity can be a way of achievement of statutory goals, but it can also be used as a method of acquisition of assets for ongoing statutory activities. ${ }^{27}$ In some other legal orders (e.g. in common law states) related business activity constitutes a convenient criterion of distinguishing tax privileges for NGOs. As a result, it acts as a set of practical tools used to deprive of tax privileges those entities that conduct typical business activity under the "disguise" of foundations, etc.

\section{Conclusions}

The crucial dilemma regarding the theory of civil society is how to arrange civil society institutions within the legal sphere. Is it the public or the private sphere? The classification problem occurs clearly in the example of foundations of private law and it is difficult to mark any demarcation line in this context. The civil society constitutes "the public sphere and is a product of private and governmental institutions, (...) that can be considered civic institutions, when they perform the normative, regulatory function towards economy and state and (...) private institutions, including natural institutions (...) of the society." ${ }^{28}$ This aspect related to distinguishing the civil society from state and economy was highlighted by Benjamin R. Barber who wrote that the civil society, as a civic space, "is an intermediary between the state authority and the private sector." ${ }^{29}$ However, in contemporary research contesting the natural dichotomy of "state vs. private" is definitely rejected, because civil society entities are established voluntarily as grassroots movements, i.e. as private initiatives, nevertheless they make effort to act for common good, thus going beyond individual or narrowly defined interests of particular groups. Such understood "specificity of relations occurring between private activities and their public goals, namely that interests are private and goals are public", 30 indisputably defines essence of social organizations, including foundations.

27 DOMINOWSKA, Joanna: Prowadzenie działalności gospodarczej przez fundacje. Studium prawne, Warszawa $2017,158$.

28 SHILS, Edward: Co to jest społeczeństwo obywatelskie, [in:] K. Michalski (eds.), Europa i społeczeństwo obywatelskie. Rozmowy w Castel Gandolfo, Wydawnictwo Znak, Kraków 1994, 10-12.

29 BARBER, Benjamin R.: Dżihad kontra McŚwiat, Warszawa 2001, 360-361.

30 BARAŃSKI, Marek: Organizacje pozarządowe w społeczeństwie obywatelskim, [in:] M. Barański (eds.), Zarządzanie organizacją pozarządową w Unii Europejskiej. Wybrane problemy, Katowice 2009, 25. 
The aforesaid division is directly related to the term of the so called third sector operating apart from the public sector (public policy and public administration) and the market sector (entrepreneurship and commercial exchange of goods). All three sectors are connected with each other by means of the network of dependencies and various similarities, however they differ so distinctively that the indicated differentiation is justified. In contrary to public authorities and similarly to market entities, social organizations are private and established as grassroots movements initiated by their incorporators, but, in contrary to market entities, and similarly to public authorities, they act for public interests, not private ones. ${ }^{31}$ It can be concluded that the civil society is rooted in the private sphere, however it develops correctly only when boundaries of this private sphere are crossed. ${ }^{32}$

While summing up the threads discussed in this paper, it should be noted that in spite of granting the seemingly explicit legal structure to foundations of private law, as separate and personified assets, the economic goal must not be foundation's goal itself. This approach is popular in the Polish doctrine ${ }^{33}$ and verdicts of Polish courts. ${ }^{34}$ Additionally, statutory activities and business activity are two different spheres of foundation's operations and should be clearly distinguished in its statute. Obviously, it does not mean they cannot mesh together, on the contrary, they often do. Moreover, the Act on Foundations implements the exemplary catalogue of achievable foundation's goals, including health protection, development of economy and science, education and upbringing, culture and arts, care and social assistance, environmental protection and preservation of historical monuments. As the lawmakers used the term "in particular", it means that this is the exemplary list of possible directions of foundation's activities. In this way the tasks required from state's point of view were indicated, that create the natural space for civil society activities in lawmakers' opinion. However, it does not mean that they should be the only background for achievement of foundation's goals, as foundations can perform every charitable activity, if it is not at odds with founder's will. On the other hand, it should be noted that foundation's management board cannot realize other goals than those defined by a founder, as it is not authorized to change their will, even when goals to be achieved would have been reasonable and socially useful by all means.

Moreover, neither social nor economic usefulness are legal terms. Foundation's business activity should be clearly correlated with its goals, because, in line with the provisions included in the art. 5 sect. 5 of the Act on Foundations, a foundation can conduct business activity to the extent used for achievement of its goals. As indicated herein, the economic goal must not be foundation's goal itself, but such an activity should be subsidiary.

It does not change the fact that some economic entities use foundation's formal and legal structure to conduct actual business activity, whose goal is, for example, tax optimization. Unfortunately, "economic usefulness" is one of these blurred terms that causes many

31 WOŹNIAK, Zbigniew: Organizacje pozarządowe w procesie budowy społeczeństwa obywatelskiego, [in:] M. Warowicki, Z. Woźniak (eds.), Aktywność obywatelska w rozwoju społeczności lokalnej, Warszawa 2001.

32 SZACKI, Jerzy: Wstęp. Powrót do idei społeczeństwa obywatelskiego, [in:] J. Szacki (eds.), Ani książę ani kupiec: obywatel. Idea społeczeństwa obywatelskiego w myśli współczesnej, Kraków 1997, 56.

33 TRZASKOWSKI, Roman: Działalność statutowa fundacja, a działalność gospodarcza fundacji, Warszawa 2003, 141.

34 The decision of the Polish Supreme Court of May 7, 2002, I CKN 162/00, Legalis. 
interpretation problems, because we can ask ourselves the question what an economically useless activity really is and what institution is authorized to state this fact ex cathedra? Foundations of private law are primary entities of social economy and main legal forms used to implement private and public ideas in Poland. Defining of this idea depends only on a founder and it has the individual character in this context. In extreme situations a founder can act as a sole arbitrator in a foundation they established (they can establish a one-person management board and appoint themselves to serve as chairman of a board for life). This individual construction process of private and public ideas distinguishes foundations from associations that, in fact, execute the same socially useful goals. However, association law ex lege imposes elements of discussion, clash of interests, pluralism and agreeing on certain matters, therefore this legal form of social economy entities is more popular in Poland where there are also foundations of public law and religious foundations whose matters are regulated on the basis of specific acts. The common feature of all three types of foundations is the idea related to execute the public function of a goal, therefore all these types, namely foundations of private law, foundations of public law and religious foundations, are elements of the civil society.

\section{References}

\section{Legal sources}

Act of April 24, 2003 on Work for Public Benefits and Voluntary Service (Journal of Laws of 2018, pos. 450).

Act of April 6, 1984 on Foundations, (Journal of Laws of 2018, pos. 1491).

Resolution of the Polish Supreme Administrative Court of December 12, 2005, II OPS 4/05, Legalis.

The Constitution of the Republic of Poland of April 2, 1997, in: Journal of Laws of 1997 no. 78 pos. 483.

The decision of the Polish Supreme Court of February 12, 2002, I CKN 1388/99, Legalis.

The decision of the Polish Supreme Court of May 7, 2002, I CKN 162/00, Legalis.

The verdict of the Polish Supreme Administrative Court of October 13, 1999, IV SA 1349/97, Legalis.

The verdict of the Polish Supreme Court of January 7, 1997, I CKN 16/96, Legalis.

ALMOND, Gabriel - VERBA, Sidney: Kultura polityczna, in: SZCZUPACZYŃSKI, Jerzy (ed.): Władza i społeczeństwo. Antologia tekstów z zakresu socjologii polityki. Scholar, Warszawa 1995. 
BARAŃSKI, Marek: Organizacje pozarządowe w społeczeństwie obywatelskim, in: BARAŃSKI, Marek. (eds.): Zarządzanie organizacją pozarządową w Unii Europejskiej. Wybrane problemy. Katowice 2009.

BARBER, Benjamin R.: Dżihad kontra McŚwiat, Warszawa 2001.

BAUMEISTER, Roy F. - BRATSLAVSKY, Ellen - FINKENAUER, Catrin - VOHS, Kathleen D.: Bad is stronger than good, in: Review of General Psychology, 2001, 5.

BURT, Ronald Stuart: Structural Holes. The Social Structure and Competition, Harvard University Press, Cambridge 1992.

ClOCH, Henryk: Prawo fundacyjne, Kraków 2007.

COHEN, Jean - ARATO, Andrew: Civil Society and Political Theory, MIT Press, Cambridge Mass 1994.

DOMINOWSKA, Joanna: Prowadzenie działalności gospodarczej przez fundacje. Studium prawne, Warszawa 2017.

FERGUSON, Adam: An Essay on the History of Civil Society, Edinburgh Univeristy Press, Edinburgh 1966.

GÓRSKI, Eugeniusz: Rozważania o społeczeństwie obywatelskim i inne studia z historii idei, IFiS PAN, Warszawa 2003.

GROTKOWSKI, Michał: Trzeci sektor w Polsce - rola i zagrożenia płynące z wypełniania funkcji i zadań administracji publicznej, "Forum Studiów i Analiz Politycznych", 2011.

HALL, Judith A.: Civil Society. Theory, History, Comparison, Polity Press, Cambridge 1995. IZDEBSKI, Hubert: Fundacje i stowarzyszenia. Komentarz, Krasnobród 2004.

KAVIRAJ, Sudipta - KHILNANI, Sunil: Civil Socjety: History and Possibilities, Cambridge 2001.

KĘPA, Marcin, - PODGÓRSKA-RYKAŁA, Joanna: Prawo o fundacjach. Komentarz do ustawy o fundacjach. Działalność fundacji w praktyce. Wzory dokumentów, C.H. Beck, Warszawa 2020.

KOTARBIŃSKI, Tadeusz: Witkiewicz: Pojęcia i twierdzenia implikowane przez pojęcie istnienia, in: "Przegląd Filozoficzny", 1936, 2. 
LAPORTA, Rafael - LOPEZ-DE-SILANES, Florencio - SHLEIFER, Andrei - VISHNY, Robert W.: Trust in large organizations, in: "American Economic Review", 1997, 57.

LIN, Nan: Social Capital. A Theory of Social Structure and Action, Cambridge University Press, New York 2001.

MICHALSKI, Krzysztof (ed.), Europa i społeczeństwo obywatelskie. Rozmowy w Castel Gandolfo, Wydawnictwo Znak, Kraków 1994.

NIEMIRKA, Bogusław: Statut fundacji, Warszawa 1995.

OFFE, Claus: Nowe ruchy społeczne. Przekraczanie granic polityki instytucjonalnej, in: SZCZUPACZYŃSKI, Jerzy (ed.): Władza i społeczeństwo, Wydawnictwo Naukowe "Scholar", Warszawa 1995.

OGRODZIŃSKI, Paweł: Pięć tekstów o społeczeństwie obywatelskim, Instytut Studiów Politycznych Polskiej Akademii Nauk, Warszawa 1991.

PIETRZYK-REEVES, Dorota: Idea społeczeństwa obywatelskiego. Współczesna debata i jej źródła, FNP, Wrocław 2004.

PODGÓRSKA-RYKAŁA, Joanna - KĘPA, Marcin: Współpraca międzysektorowa jednostek samorządu terytorialnego z organizacjami pozarządowymi, Wydawnictwo Libron, Kraków 2020.

SHILS, Edward: Co to jest społeczeństwo obywatelskie, in: MICHALSKI, Krzysztof (ed.), Europa i społeczeństwo obywatelskie. Rozmowy w Castel Gandolfo, Wydawnictwo Znak, Kraków 1994.

SIDANIUS, Jim - PRATTO, Felicia: Social dominance: An intergroup theory of social hierarchy and oppression, Cambridge University Press, New York 1999.

SOIN, Maciej: Filozofia Stanisława Ignacego Witkiewicza, Ossolineum, Wrocław 2002.

STECKI, Leopold: Fundacja. Część pierwsza, Toruń 1996.

SUSKI, Paweł: Stowarzyszenia i fundacje, Warszawa 2018.

SZACKI, Jerzy: Ani książę, ani kupiec - obywatel: idea społeczeństwa obywatelskiego w myśli współczesnej, Znak, Kraków 1997.

SZACKI, Jerzy: Wstęp. Powrót do idei społeczeństwa obywatelskiego, in: SZACKI, Jerzy (eds.): Ani książę ani kupiec: obywatel. Idea społeczeństwa obywatelskiego w myśli współczesnej, Kraków 1997. 
TRZASKOWSKI, Roman: Działalność statutowa fundacja, a działalność gospodarcza fundacji, Warszawa 2003.

WITKOWSKA, Marta and WIERZBICKI, Andrzej (eds.): Społeczeństwo obywatelskie, Oficyna Wydawnicza ASPRA-JR, Warszawa 2005.

WNUK-LIPIŃSKI, Edmund: Socjologia życia publicznego, Warszawa 2005.

WOLTER, Aleksander: Prawo cywilne, Warszawa 1996.

WOŹNIAK, Zbigniew: Organizacje pozarządowe w procesie budowy społeczeństwa obywatelskiego, in: WAROWICKI, Mirosław - WOŹNIAK Zbigniew (eds.): Aktywność obywatelska w rozwoju społeczności lokalnej, Warszawa 2001.

WRZEŚNIEWSKI, Paweł: Ustawa o fundacjach. Komentarz praktyczny, Warszawa 2011.

\section{Authors}

dr Joanna Podgórska-Rykała

Pedagogical University of Cracow

Department of Social Sciences

Institute of Political Sciences and Administration

ul. Podchorążych 2, Kraków, Poland

joanna.podgorska-rykala@up.krakow.pl

dr Marcin Kępa

Pedagogical University of Cracow

Department of Social Sciences

Institute of Law and Economcs

ul. Podchorążych 2, Kraków, Poland

marcin.kepa@up.krakow.pl 